Relations industrielles

Industrial Relations

\title{
McCollester, Charles, ed., Fighter with a Hearth: Writings of Charles Owen Rice, Pittsburgh Labor Priest
}

\section{Martin Moran}

Volume 52, numéro 3, 1997

URI : https://id.erudit.org/iderudit/051194ar

DOI : https://doi.org/10.7202/051194ar

Aller au sommaire du numéro

Éditeur(s)

Département des relations industrielles de l'Université Laval

ISSN

0034-379X (imprimé)

1703-8138 (numérique)

Découvrir la revue

Citer ce compte rendu

Moran, M. (1997). Compte rendu de [McCollester, Charles, ed., Fighter with a Hearth: Writings of Charles Owen Rice, Pittsburgh Labor Priest]. Relations industrielles / Industrial Relations, 52(3), 660-662.

https://doi.org/10.7202/051194ar

Tous droits réservés @ Département des relations industrielles de l'Université Laval, 1997
Ce document est protégé par la loi sur le droit d'auteur. L'utilisation des services d'Érudit (y compris la reproduction) est assujettie à sa politique d'utilisation que vous pouvez consulter en ligne.

https://apropos.erudit.org/fr/usagers/politique-dutilisation/ 


\section{Fighter with a Heart: Writings of Charles Owen Rice, Pittsburgh Labor Priest}

edited by Charles MCCOLLESTER, Pittsburgh: University of Pittsburgh Press, 1996, 244 p., ISBN-0-8229-5619-5.

"American Exceptionalism" (less pretensiously and less ethnocentrically United States Exceptionalism) is essentially Euro-referential. Rather than ask why the U.S. labour movement is less class conscious and socialistic than its European progenitors, an even more interesting and revealing question is why the Canadian labour movement, most of whose organizations were spawned by the AFL or the CIO, is so much healthier and more left in its politics than the AFLClO? This remarkable book by and about this remarkable man, Msgr. Charles Owen Rice, provides a unique perspective from which to contemplate these U.S.-Canadian differences.

The conventional explanation of the origins of U.S.-Canadian union differences as seen by Seymour Martin Lipset is U.S. individualism vs Canadian communitarianism. (Life, liberty and the pursuit of happiness vs peace, order and good government.) The "ususal suspects" identified as sources of U.S. uniqueness are: the open frontier providing the opportunity to own land, the then primary means of production and the western escape valve for those who otherwise might have become radical agitators; shortage of labour leading to "the people of plenty"; the obscuring of class differences by such divisive cultural artifacts as language, religion, nationality, etc. (All of which obviously differentiate the U.S. and Canada.)

For those for whom the Lipset (akin to Perlman, Taft, Gompers, etc.) formulation is inadequate, a more useful question might be why have internal union struggles - Communist vs. anti-Communist in simplistic shorthand - had such different impacts on the strength and character of the U.S. and Canadian labour movements in the post World-War II period?
Among the many answers offered are: the much more supportive role of government (no Taft-Hartley Law in Canada); the more intensive cold war anti-radicalism of U.S. state and society; the traumatic divisiveness of the "peculiar" (to the U.S.) institution of slavery (followed by legalized segregation and continuing racism) which undermined class consciousness through an emphasis on color distinctions thus providing not only a nonunion haven for U.S. manufacturers in southern right-to-work states but, of more lasting impact, a Dixiecrat bloc in Congress which effectively prevents either prounion or pro-worker legislation in the U.S.

But another explanation of the reason the weaker Canadian movement has outstripped its U.S. progenitors in recent decades - one which is powerfully illustrated in this fascinating book - is that in the U.S. the anti-left labour leadership was so overwhelmingly a Catholic leadership, both in the persons of the union activists and in the active role of Catholic clergy, while the Canadian unionists who contended for power against Communist sympathetic leaders were themselves self-identified leftists - socialists with a capital or small " $\mathrm{s}$ ".

Whereas the position of the Canadian Catholic Church vis a vis unions (until the Quiet Revolution of the sixties) was, largely, "a pox on all your secular houses" and was geographically centered in Quebec, Catholic clergy in the U.S. had a long history of influence on U.S. union leaders who were disparately Catholic and geographically dispersed. The Church had an impact broader than its geographic reach and deeper than the numbers of Catholic unionists it influenced. Those effects were unusually intense partly because they were religious; as Spinoza noted, of all hatred none is deeper and more tenacious than that which springs 
from extreme devotion or piety, and is itself cherished as pious. Or, more colloquially, as Mr. Dooley Sez, "a f'natic does what he thinks th' Lord wud do if He only knew th' facts in th' case". (Irish dialect newspaper column by Peter Finley Dunne.)

No individual played a more powerful or prominent role than Fr. Charles Owen Rice. He was more than just Pittsburgh's "Labor Priest": he gave the invocation at the first $\mathrm{CIO}$ convention; he organized the Catholic Radical Alliance which became part of the Association of Catholic Trade Unionists (ACTU). He did more than pray for downtrodden workers; he heeded Mother Jones injunction to "pray for the dead and fight like hell for the living". He led picket lines, inspired strikers at rallies, gave counsel to workers attempting to organize unions, and created a labour school within the church. He was counselor and confidant of the first CIO President, Philip Murray.

He was a cleric with a clear class consciousness. In all of the many movements with which he identified: Irish Independence; union organizing; civil rights; peace; jobs, etc., there was always an "Us and Them" class analysis in his commentary. If Oliver Wendell Holmes was right, that " $[\mathrm{A}]$ man must share the action and passion of his times at risk of being judged not to have lived", this was a man who lived. He built on but went beyond the Papal Encyclical's philosophical and moral support for workers' rights as individuals; he proclaimed that only the collective power of unionism was a meaningful way to enforce those rights. He wore his clerical collar like a badge, insisting that it indicated where he belonged - with the afflicted. Nor did he limit his ministry to comforting the afflicted; he revelled in afflicting the comfortable. He held, "...labor to be not just a worthy cause, but virtually a holy one."

Seldom does one life so well exemplify a historic period. Even more rarely does so active a participant manage to be so acute and objective an observer of so many of the struggles of his times. Rarely does this intense activism with such absolute commitment also permit sufficient distance - and even more rarely such clear and compelling writing. Rice was able to not only observe objectively but, most unusually, to publicly acknowledge error - and to ask forgiveness from those individuals and institutions he felt he had treated unjustly. His writing is concise, clever and ever critical.

His roles - ACTU leader, collaborator with the House Un-American Activities Committee (HUAC), advisor to the right in its effort to win control from the incumbent left leadership of United Electrical Workers Local 601 at Pittsburgh's Westinghouse Electric Plant - led him to be perceived as redbaiter extraordinaire. As much as anyone he was the creator of the International Union of Electrical Workers which displaced UE within the $\mathrm{ClO}$. (This expulsion was a Phil Murray decision which Rice retrospectively regretted; he felt that it contributed to the stifling of all voices of dissent within the movement.)

He himself never hesitated to dissent - loudly. His profound support of unionism did not lead to silence when he felt official policy or practice to be inconsistent with his views of justice, and the notion of solidarity with all workers. He was an early leader in the movement against the Vietnam War and was both an influence on and shield for those labor leaders who joined him in that unpopular cause. His concerns for the lack of opportunities for African Americans to obtain union membership in (and therefore jobs within) the building and construction trades led to some very direct and very disagreeable confrontations with union officials.

Even more painful for Msgr. Rice was the break with the leadership of the Steelworkers' union which came as a consequence of his support of dissidents within the organization. It was particularly sad 
and ironic that this occurred even as the founding president of the union lay buried in the graveyard of St. Anne's Church where Rice served as pastor during this time of estrangement. It was a Canadian, Lynn Williams, who rebuilt the relationship between Phil Murray's union and Phil Murray's friend.

The book is edited with loving care by Dr. Charles McCollester. While the editor is obviously a great admirer of Msgr. Rice, the editing is done with scholarly objectivity. Although the editor provides an historical and biographical framework, primarily he lets Rice speaks for himself. The writings are drawn mainly from a weekly column which Rice wrote over a period of sixty years in the Pittsburgh Catholic (with a several year hiatus when the incumbent Bishop took umbrage at the Monsignor's column critical of a Cardinal for using seminarians as scabs during a gravediggers' strike). Accompanying the writings are a collection of photos of Rice living out his beliefs which by themselves are worth the price of the book $(\$ 49.95$, hardcover; $\$ 19.95$, soft). Buy it, you'll like it!
The flavour of the Rice writings - both content and style - is reflected in the titles of his columns. A few examples will have to suffice: The Irish Revolt, The Dynamite of the Encyclicals, Can a Catholic Accept the Outstretched Hand of a Communist?, Catholic Contempt of the Negro Must End, Catholics and AntiSemitism, Westinghouse and Reds Again, A Company Union Finally Succceeds in Standing on Its Own Feet, How to DeControl Your Union of Communists, The Struggle for UE, The Tragic Purge of 1948, Confessions of an Anti-Communist, Do We Belong in Vietnam, Reuther - R.I.P., Jock Yablonski the Rebel, Nuns and Unions, Mighty Steel Strikes Us Out, We Need a Two - Way Class War, Persian Gulf War Is Not Just, It Is Not Burning that Dishonors Flag, Father Aristede Is My Kind of Guy, Airline Pilots Versus Predators, Steve Nelson: An Honorable Antagonist, The Lord Hears the Cry of the Poor! So Should We.

MARTIN MORAN

Indiana University of Pennsylvania

\section{L'État, l'autonomie collective et le travailleur - Etude comparée du droit italien et du droit français de la représentativité syndicale}

par Stamatina YANNAKOUROU, Bibliothèque du droit privé, tome 247, Paris:

L.G.D.J., 1995, 393 p., ISBN 2-275-00265-0.

Comment une étude comparée, version remaniée d'une thèse de doctorat, portant sur deux régimes juridiques de représentativité syndicale a priori si éloignés de la formule nord-américaine les régimes français et italiens -, peutelle interpeller d'une façon significative le juriste ou le spécialiste des relations industrielles dont le quotidien le rattache à ce dernier modèle?

En premier lieu, l'étude dégage les rapports fondamentaux, les "modes de communication ", entre la négociation, ou mieux, l'autonomie collective et la loi, l'ordre juridique étatique. Le choix des systèmes confrontés assure déjà la fécon- dité de la comparaison : l'Italie " est l'unique pays parmi les démocraties de l'Europe occidentale qui ignore en principe la réglementation législative des rapports de travail " (p. 1) ; l'encadrement législatif des syndicats et de la négociation collective est, au contraire, prononcé en France. L'exposé développement historique de l'un et l'autre systèmes et l'analyse détaillée des apports législatifs, jurisprudentiels et doctrinaux qui les ont façonnés permettent de dégager avec force et netteté leurs orientations plutôt divergentes.

La trame est celle du pluralisme juridique dont est imprégnée la culture 